\title{
The effects of acute and chronic protein depletion and accretion on plasma concentrations of insulin-like growth factor-1, fibronectin and total protein for ruminants nourished by intragastric infusion of nutrients
}

\author{
BY S. M. LIU*, N. A. MACLEOD, Q. J. LUO, X. B. CHEN, D. J. KYLE, P. NICOL, \\ C. G. HARBRON AND E. R. ØRSKOV†
}

Rowett Research Institute, Greenburn Road, Bucksburn, Aberdeen AB21 9SB

(Received 5 June 1995 - Revised 20 January 1997 - Accepted 11 February 1997)

\begin{abstract}
The relationships of $\mathbf{N}$ input or protein status and the concentrations of serum insulin-like growth factor-1 (IGF-1), plasma fibronectin (FN) and total protein (TP) were examined in three experiments with steers and sheep nourished by intragastric infusion of nutrients. In Expt 1, three steers $(340 \mathrm{~kg}$ live weight) were infused with three levels of volatile fatty acids $(0,300$ and $600 \mathrm{~kJ} / \mathrm{kg}$ metabolic weight $\left(W^{0.75}\right)$ per d) and six levels of casein $(0,200,400,650,1500$ and $2500 \mathrm{mg}$ $\mathrm{N} / \mathrm{kg} \mathrm{W}^{\mathbf{0 . 7 5}}$ per d). Each $\mathrm{N}$ treatment was imposed for $5 \mathrm{~d}$. In Expts 2 and 3, five groups of sheep (about $35 \mathrm{~kg}$ live weight) were infused with casein at $500 \mathrm{mg} \mathrm{N} / \mathrm{kg} \mathrm{W}^{\mathbf{0 . 7 5}}$ per $\mathrm{d}$ for 2 weeks followed by 1500,500 or $50 \mathrm{mg} \mathrm{N} / \mathrm{kg} \mathrm{W}^{0.75}$ per $\mathrm{d}$ in Expt 2, and in Expt 3, with $100 \mathrm{mg} \mathrm{N} / \mathrm{kg} \mathrm{W}^{0.75}$ per d for 6 weeks or $10 \mathrm{mg} \mathrm{N} / \mathrm{kg} \mathrm{W}^{0.75}$ per $\mathrm{d}$ for 4 weeks. Non-protein energy was maintained constant at $500 \mathrm{~kJ} / \mathrm{kg} \mathrm{W}^{0.75}$ per d throughout. Daily $\mathrm{N}$ balance and total body $N$ content at the end were measured, and protein status was defined as a percentage of cumulative $\mathbf{N}$ accretion or depletion in relation to the total body $N$ content at maintenance. It was found that IGF-1 and FN responded rapidly and substantially to altered $N$ input, and that when daily $N$ input was maintained constantly at sub-maintenance, their continuous declines were related closely to progressive protein depletion in the sheep. Plasma TP concentration was independent of $N$ input when $N$ input was altered acutely in the steers, but declined significantly and gradually with severe, chronic body protein depletion in the sheep. Plasma content of TP in the sheep however reduced acutely with a reduction in $\mathbf{N}$ input. Plasma volume fell substantially over the first 2 weeks of protein depletion, compensating for the declines in TP content and maintaining TP concentration plateau. The possible implications of the changes in TP concentration and content (concentration $\times$ volume) to body protein loss in sheep are discussed.
\end{abstract}

IGF-1: Fibronectin: Protein status: Ruminants

The estimation of changes in total body $\mathrm{N}$ can be achieved using some advanced noninvasive laboratory techniques such as neutron activation analysis, tracer dilution methods and some instrument techniques (reviewed by Gibson, 1990 and Ellis, 1992). However these techniques cannot easily be applied in practical situations. Several blood biochemical metabolites have therefore been studied as potential indicators of protein status in human subjects and animals (see reviews by Gibson, 1990; Young et al. 1990). The liver plays a

\footnotetext{
* Present address: Division of Animal Production, CSIRO, Underwood Avenue, Floreat Park, Wembley, WA 6014, Australia.

$\dagger$ For reprints.
} 
central role in the regulation of whole-body protein metabolism by reconstituting absorbed and degraded tissue amino acids, removing $\mathrm{N}$ in the body by production of urea, using amino acids in gluconeogenesis, influencing protein synthesis via production of its insulinlike growth factor-1 (IGF-1) and producing and exporting plasma proteins to transport nutrients. It may, therefore, be possible to use the metabolic products which reflect liver function as an indicator of whole-body protein status. Plasma IGF-1 (Baxter, 1986) fibronectin (FN) (Tamkun \& Hynes, 1983) and plasma proteins are mainly produced in the liver. The changes in the circulating concentrations of IGF-1 have been found to be associated with dietary nutrient inputs and nutritional status in humans (Baxter, 1986; Clemmons \& Underwood, 1991) and sheep (MacRae et al. 1990). The plasma concentration of FN has been recognized as a useful nutritional marker in human subjects (Scott et al. 1982; Kirby et al. 1985; Chadwick et al. 1986; Buonpane et al. 1989). The present study examined these potential indicators, using intragastric infusions of nutrients to sheep and steers to control precisely inputs of protein so that acute and chronic changes in protein status could be accurately defined.

\section{MATERIALS AND METHODS}

\section{Intragastric infusion}

The steers and lambs used in this study were housed in metabolic cages and nourished completely by intragastric nutrient infusions (MacLeod et al. 1982). The animals were surgically prepared with a permanent rumen cannula and an abomasal catheter. The animals were established on the infusion regimen by initially infusing a mixture of volatile fatty acids (VFA) containing acetic, propionic and butyric acids in the molar proportions $0.65: 0.25: 0 \cdot 10$ respectively at a level of $100 \mathrm{~kJ} / \mathrm{kg}$ metabolic weight $\left(\mathrm{W}^{0.75}\right)$ per $\mathrm{d}$. This was then increased gradually to $500 \mathrm{~kJ} / \mathrm{kg} \mathrm{W}^{0.75}$ per $\mathrm{d}$ over $10 \mathrm{~d}$. The infused casein initially provided $\mathrm{N}$ at $100 \mathrm{mg} / \mathrm{kg} \mathrm{W}^{0.75}$ per $\mathrm{d}$, and was then increased to $500 \mathrm{mg} / \mathrm{kg} \mathrm{W}^{0.75}$ per d over a period of $6 \mathrm{~d}$. The experimental treatments were imposed subsequently. The $\mathrm{pH}$ and osmotic pressure of the rumen contents were checked twice daily.

\section{Treatments and sampling}

Experiments were designed to produce different protein status: the animals were subjected to both short and long periods of protein depletion or accretion. Three experiments were performed.

In Expt 1, three Simmental crossbred steers (average live weight $340 \mathrm{~kg}$ ) were given three levels of energy: 0,300 and $600 \mathrm{~kJ} / \mathrm{kg} \mathrm{W}^{0.75}$ per d from VFA according to a $3 \times 3$ Latin-square design. Six levels of protein $\left(0,200,400,650,1500\right.$ and $2500 \mathrm{mg} \mathrm{N} / \mathrm{kg} \mathrm{W}^{0.75}$ per d) were superimposed as sub-plots at each level of VFA. Each protein treatment lasted for 5 or $6 \mathrm{~d}$ (short-term). A blood sample was withdrawn from the jugular vein on the last day of each protein treatment. This experiment was designed to examine the effects of acute changes in protein input on the circulating concentrations of IGF-1, FN and total protein (TP) in plasma.

In Expt 2, ten 7-month-old Suffolk $\times$ Greyface male castrated lambs (initial live weight $36.9($ SD 7.9$) \mathrm{kg}$ ) were maintained on $500 \mathrm{mg} \mathrm{N} / \mathrm{kg} \mathrm{W}^{0.75}$ per $\mathrm{d}$ for a period of 2 weeks (maintenance period). They were subdivided into three groups and infused with 1500 (three sheep), 500 (three sheep) or $50 \mathrm{mg} \mathrm{N} / \mathrm{kg} \mathrm{W}^{0.75}$ per d (four sheep) for a period of 6 weeks (treatment period). The energy input from VFA was maintained at 
$500 \mathrm{~kJ} / \mathrm{kg} \mathrm{W}^{0.75}$ per $\mathrm{d}$ for all the animals. Blood samples were taken from the jugular vein on days 4 and 11 of the maintenance period, and on days $1,2,3,7,14,21,28,35$ and 42 of the treatment period. The serum and plasma samples were stored at $-20^{\circ}$ for subsequent analysis of concentrations of IGF-1, FN and TP. Whole-body protein synthesis was measured on day 11 of the maintenance period, and days 2, 21 and 42 of the treatment period by use of constant intravenous infusion of $\left[1-{ }^{13} \mathrm{C}\right]$ leucine, and the results have been reported (Liu et al. 1995). Daily $\mathrm{N}$ balance measurements were performed throughout (Ørskov \& MacLeod, 1982).

In Expt 3, six Suffolk $\times$ Greyface male castrated crossbred sheep of 33 (SD 1.8) $\mathrm{kg}$ average live weight and 6 months of age were used. Casein provided $500 \mathrm{mg} \mathrm{N} / \mathrm{kg} \mathrm{W}^{0.75}$ per $\mathrm{d}$ for 2 weeks (maintenance period) and was then reduced either to $100 \mathrm{mg} / \mathrm{kg} \mathrm{W}^{0.75}$ per $\mathrm{d}$ for a period of 6 weeks for three sheep, or to $10 \mathrm{mg} / \mathrm{kg} \mathrm{W}^{0.75}$ per $\mathrm{d}$ for 4 weeks for the remaining three sheep. Non-protein energy was provided at $500 \mathrm{~kJ} / \mathrm{kg} \mathrm{W}^{0.75}$ per $\mathrm{d}$, half being from VFA and half from glucose. This energy level was maintained throughout the experimental period. Blood sampling procedures and daily $\mathrm{N}$ balance measurement were the same as in Expt 2. Plasma volume was measured on day 11 of the maintenance period and thereafter at weekly intervals during the treatment periods to allow for calculations of plasma TP content (g).

These two sheep experiments were designed to examine the effects of chronic body protein accretion or depletion at various rates on the concentrations of IGF-1, FN and TP.

\section{Measurements and analyses}

Measurements and analyses consisted of analyses of concentrations of serum IGF-1, plasma FN and TP, plasma volume and total body $\mathrm{N}$ content.

Insulin-like growth factor-1 concentration. IGF-1 concentration in the sheep was measured by radioimmunoassay (Bruce et al. 1991). The same method was employed in the samples from the steers after examination of the recovery of standard IGF-1 (Bachem (UK) Ltd, Saffron Walden, Essex; Cat. no. DGRO10) added into the ethanol-acid extracted samples. The measured recovery of added standard, defined as the slope of linear regression equation of the total IGF-1 measured against the added standard IGF-1, was 0.93 (SED $0.09, n 8$ ) and appeared to be satisfactory. The procedure developed by Bruce $e t$ al. (1991) was therefore used directly for steer serum in this study.

Fibronectin concentration. FN concentrations in plasma (EDTA) were measured using a modified ELISA method described by Voller \& Bidwell (1980). Bovine FN and the antibody were obtained from Calbiochem Novabiochem (UK) Ltd (Nottingham, Notts.). Since ovine FN and the antibody were not available, the possibility of the cross-reaction of plasma FN from sheep with the antibody of the bovine FN antiserum was examined. The inhibition curves of bovine and ovine plasma samples with bovine FN antiserum were compared and the two curves were parallel. The FN concentration in sheep plasma was therefore measured using the same system as for the plasma from steers.

Total body nitrogen content. Total body $\mathrm{N}$ content in the sheep was determined at the end of the experiment. The animals were shorn, killed and the digesta were removed. The fleece-free empty body was minced, weighed, sampled and then freeze-dried. The $\mathrm{N}$ concentrations of the samples were determined by Kjeldahl procedure (Davidson et al. 1970 ), the total $\mathrm{N}$ content was then calculated. The fleece was dried at $100^{\circ}$ and the $\mathrm{N}$ content calculated by multiplying the dry weight by 0.134 (Agricultural Research Council, 1980). The initial total body $\mathrm{N}$ was extrapolated from the final total body $\mathrm{N}$ by subtracting 
the cumulative $\mathrm{N}$ balance (excluding the fleece- $\mathrm{N}$ ) over the whole period to determine the alteration in protein mass $(\mathrm{N} \times 6 \cdot 25)$.

Plasma volume. Plasma volume was measured using Evans Blue (EB) as the indicator (Foldager \& Blomqvist, 1991). For each measurement a pre-injection blood sample was taken to be used as the blank for the following samples. A dose of $10 \mu \mathrm{g}$ EB in $5 \mathrm{ml}$ sterilized physiological saline was then injected via a jugular catheter and the catheter was immediately flushed with $2 \mathrm{ml}$ saline. Four blood samples, each of $2 \mathrm{ml}$, were taken at 2,5 , 10 and 15 min intervals after injection, from the jugular catheter at the other side. The plasma was harvested after centrifuging the samples at $3000 \mathrm{~g}$ for $15 \mathrm{~min}$ at room temperature. The absorbance of the plasma samples at $620 \mathrm{~nm}$ was read with the preinjection plasma sample used as the blank. The corresponding concentrations of EB were calculated from the standard curve, and time curves then derived. The concentration of EB at the time of injection was calculated by extrapolation from the time curve.

TP concentration in plasma was measured using an automated procedure derived from that of Gornall et al. (1949).

\section{Statistical analysis}

Expt 1: the effects of $\mathrm{N}$ and energy inputs on the concentrations of IGF-1, FN and TP were derived by factorial analysis. Both period and animal were treated as blocks, and $\mathrm{N}$ and VFA energy as factors.

Expts 2 and 3: to reduce the differences in the initial concentrations of IGF-1, FN and TP of the sheep, the percentage changes over the treatment period were calculated using the initial values as the base. These derived treatment effects were then used in further statistical analysis. Since the measurements were repeated weekly, the influence of $\mathrm{N}$ input on the concentrations of IGF-1, FN and TP over the whole treatment period were examined by REML procedure with Wald test. Both $\mathrm{N}$ input and day were treated as fixed effects. The time-related effects were examined by both comparing the treatment effects at the same day (between the three $\mathrm{N}$ inputs), and comparing them with their initial measures at maintenance (within the group).

All statistical analyses of the data were performed using Genstat 5, Release 3 (Lawes Agricultural Trust, 1993).

\section{RESULTS}

Expt 1. The concentrations of insulin-like growth factor-1, fibronectin and total protein in steers

The concentrations of IGF-1 and FN in the steers, as shown in Fig. 1(a), were significantly associated with the input levels of $\mathrm{N}(P<0.001)$ and VFA $(P=0.01)$. There was no significant $(P=0.86)$ interaction between $\mathrm{N}$ and VFA inputs.

As shown in Fig. 1(b), gradual increments in $\mathrm{N}$ input from 0 up to $2500 \mathrm{mg} / \mathrm{kg} \mathrm{W}^{0.75}$ per d significantly elevated the concentrations of FN $(P<0.001)$ even though the responses at low $\mathrm{N}$ levels of between 0 and $200 \mathrm{mg} / \mathrm{kg} \mathrm{W}^{0.75}$ per d were very weak. There was no effect of infusion of different amounts of VFA although the lowest concentrations were observed at nil VFA $(P=0.93)$. There was no significant interaction between $\mathrm{N}$ and VFA inputs $(P=0.99)$.

The concentrations of plasma TP in the three steers averaged $75.8,80.4$ and 71.5 (SED $1.7) \mathrm{g} / 1(P=0.07)$ for the three levels of VFA input, and $75.8,76.4,75 \cdot 0,75 \cdot 7,75.9$ and 

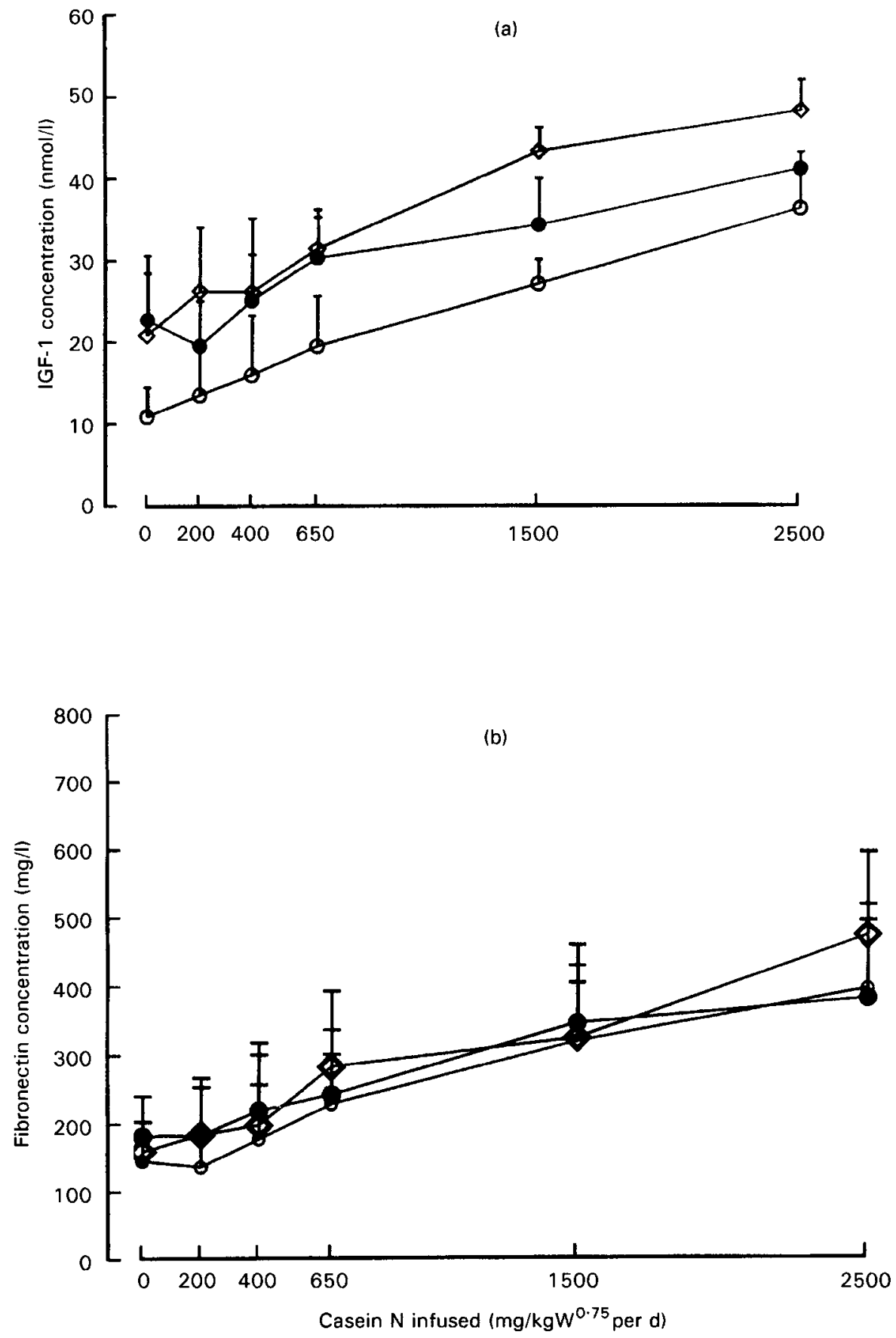

Fig. 1. Expt 1. The concentrations of (a) serum insulin-like growth factor-1 (IGF-1) and (b) plasma fibronectin in three steers infused with various amounts of casein and volatile fatty acids (VFA). Each nitrogen input level was maintained for $5 \mathrm{~d}$ and a blood sample was taken on the last day. Values are means with their standard errors represented by vertical bars. (O), $0 ;(0), 300 ;(\diamond) 600 \mathrm{~kJ}$ VFA $/ \mathrm{kg} \mathrm{W}^{0.75}$ per d. 
76.6 (SED 1.6) $\mathrm{g} / \mathrm{l}(P=0.94)$ for the six levels of $\mathrm{N}$ input respectively. There were no significant responses of $\mathrm{TP}$ to acute changes in $\mathrm{N}$ input.

\section{Expts 2 and 3. Protein status, and the concentrations of insulin-like growth factor-1, fibronectin and total protein in sheep}

Cumulative $\mathrm{N}$ balance (CNB) of the sheep over the 6 weeks of treatment period was calculated from the daily $\mathrm{N}$ balance with the fleece- $\mathrm{N}$ retention deducted. In Expt 2, the values were 228 (SD 228), 30 (SD 7) and -177 (SD 22) g for $\mathrm{N}$ inputs of 1500,500 and $50 \mathrm{mg} / \mathrm{kg} \mathrm{W}^{0.75}$ per $\mathrm{d}$. The measured fleece-free empty body total $\mathrm{N}$ (TN) values at the end of the experiments were 932 (SD 86), 671 (sd 139) and 624 (SD 132) g, and the initial TN was then extrapolated by subtracting the CNB from the final TN. The rates of protein depletion and accretion through the treatment period were calculated from $\mathrm{CNB}$ as percentages of the initial TN $(\mathrm{CNB} / \mathrm{TN} \times 100)$, and are shown in Fig. 2. The overall depletion or accretion rates were $+33.2,+3.8$ and -22.1 (SED 6.9) $\%,(P<0.001)$ for the three $\mathbf{N}$ inputs. These rates are defined as the protein status in this study.

In Expt 3 with $\mathrm{N}$ inputs of 100 or $10 \mathrm{mg} / \mathrm{kg} \mathrm{W}^{0.75}$ per $\mathrm{d}$ for 6 and 4 weeks respectively, the CNB were -106 (SD 6) $v .-94$ (SD 6) $\mathrm{g}$, the final TN values 568 (SD 27) v. 540 (SD 21) $\mathrm{g}$, and the overall depletion rates were $-15.7 \%$ and $-14.8 \%$ for $\mathrm{N}$ inputs of 100 (6 weeks) and $10 \mathrm{mg} / \mathrm{kg} \mathrm{W}^{0.75}$ per d (4 weeks only) respectively. The daily depletion rates averaged -0.37 and -0.53 (SED 0.008) \%, $(P<0.001$ ). Thus the lower N input resulted in faster body depletion.

The serum concentrations of IGF-1 in the sheep are shown in Fig. 3. In Expt 2, the concentrations averaged $10.8,8.9$ and $11.4($ SED 2.7$) \mathrm{nmol} / 1(P=0.59)$ initially at maintenance. After the $\mathrm{N}$ input was altered to a high or low level, the concentrations were significantly different $(P=0.03)$ from day 1 , and then diverged depending on $\mathrm{N}$ input. The interactions between $\mathrm{N}$ input and day of the treatments were significant $(P<0 \cdot 01)$. After 6

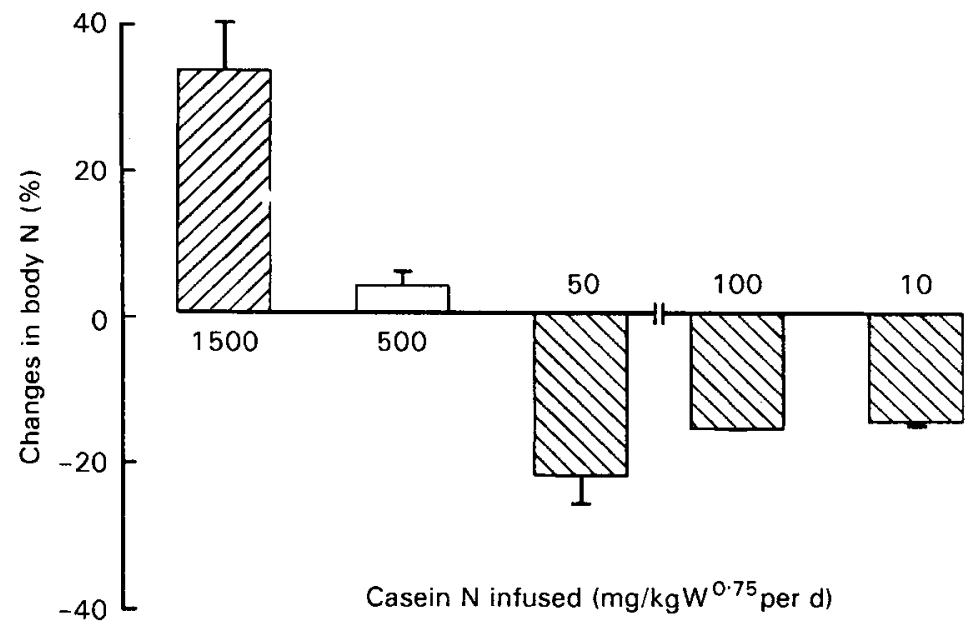

Fig. 2. Changes in protein status in sheep infused with casein at 1500,500 and $50 \mathrm{mg} \mathrm{N} / \mathrm{kg} \mathrm{W}^{0.75}$ per d for 6 weeks (Expt 2) and at $100 \mathrm{mg} \mathrm{N} / \mathrm{kg} \mathrm{W}^{0.75}$ per d for 6 weeks or $10 \mathrm{mg} \mathrm{N} / \mathrm{kg} \mathrm{W}^{0.75}$ per d for 4 weeks (Expt 3). Energy provided by volatile fatty acids (VFA) (Expt 2) or VFA + glucose (Expt 3) was constant at $500 \mathrm{~kJ} / \mathrm{kg} \mathrm{W}^{0.75}$ per d. Protein status is defined as the cumulative nitrogen balance (excluding nitrogen retained in the fleece) as a percentage of the initial empty-body total nitrogen. Values are means with their standard errors represented by vertical bars for three sheep in each group except the $50 \mathrm{mg} / \mathrm{kg} \mathrm{W}^{0.75}$ per d input group, in which $n 4$. 
weeks, the magnitudes of changes were $+130,+29$ and -73 (SED 58) $\%(P=0.02)$ for $\mathrm{N}$ inputs of 1500,500 and $50 \mathrm{mg} / \mathrm{kg} \mathrm{W}^{0.75}$ per d respectively when related to their initial maintenance values. The average daily increment in IGF-1 concentration on the $\mathrm{N}$ input of $1500 \mathrm{mg} / \mathrm{kg} \mathrm{W}^{0.75}$ per $\mathrm{d}$ was $1.3 \mathrm{nmol} / 1$ over the first $3 \mathrm{~d}$, and then $0.6 \mathrm{nmol} / 1$ until day 14. The values stabilized thereafter at a plateau of approximately $20 \mathrm{nmol} / \mathrm{l}$. In contrast, with a $\mathrm{N}$ input of $50 \mathrm{mg} / \mathrm{kg} \mathrm{W}^{0.75}$ per $\mathrm{d}$, the concentrations fell by $1.7 \mathrm{nmol} / 1 \mathrm{per} \mathrm{d}$ over the first $3 \mathrm{~d}$, and continued to decline at a daily rate of $0.1 \mathrm{nmol} / 1$ until the end of the treatment period.

As shown in Fig. 3(b), serum IGF-1 concentrations in Expt 3 averaged 22.1 and 22.3 (SED 3$) \mathrm{nmol} / 1(P=0.94)$ initially at maintenance, and fell substantially and continuously after the $\mathrm{N}$ input was reduced to 100 or $10 \mathrm{mg} / \mathrm{kg} \mathrm{W}^{0.75}$ per $\mathrm{d}$. The lower $\mathrm{N}$ input resulted in more decrements in IGF-1 concentration with time, but the difference was significant $(P=0.047)$ only on day 28 .

The plasma concentrations of FN and TP in the sheep in Expt 2 are shown in Fig. 4. The initial FN concentrations were 164, 193 and 211 (SED 9) $\mathrm{mg} / \mathrm{l}(P<0.001$ ) at maintenance. The reason for these initial differences between the groups is not known. After the 6 weeks of treatment, the FN concentrations were 280,217 and 134 (SED $34) \mathrm{mg} / \mathrm{l}(P=0.007)$ for the $\mathrm{N}$ inputs of 1500,500 and $50 \mathrm{mg} / \mathrm{kg} \mathrm{W}^{0.75}$ per d respectively. The overall changes were $+71,+13$ and -37 (SED 19) \% $(P<0.001)$. The concentrations diverged gradually with time, related to the high and the low $\mathrm{N}$ inputs, and the differences became, and remained, significant from day $2(P=0.017)$ onwards. The daily increments in $\mathrm{FN}$ concentration over the first $3 \mathrm{~d}$ at the high $\mathrm{N}$ input of $1500 \mathrm{mg} / \mathrm{kg} \mathrm{W}^{0.75}$ per $\mathrm{d}$ averaged $24 \mathrm{mg} / 1$, and $1.1 \mathrm{mg} / 1$ over the following $39 \mathrm{~d}$, whereas the corresponding daily decrements at the low $\mathrm{N}$ input of $50 \mathrm{mg} / \mathrm{kg} \mathrm{W}^{0.95}$ per d averaged 10 and $0.9 \mathrm{mg} / 1$ respectively.

The plasma concentrations of TP in the sheep in Expt 2, as shown in Fig. 4(b), were initially $72.1,68.7$ and $71.6($ SED 2.7$) \mathrm{g} / 1(P=0.41)$ at maintenance, but by the end of the 6-week treatment period, were 80.0, 65.8 and $51.2(\operatorname{SED} 5.8) \mathrm{g} / 1(P=0.003)$ for $\mathrm{N}$ inputs of 1500,500 and $50 \mathrm{mg} / \mathrm{kg} \mathrm{W}^{0.75}$ per d. The overall changes were $+11,-4$ and -29 (SED 7) \% $(P=0.002)$ respectively. There were significant interactions between $\mathrm{N}$ input and the day of treatment $(P<0.01)$. The divergence of the concentration between the high and low $\mathrm{N}$ inputs became significant $(P=0.03)$ from week 3 and developed onwards. However, although TP concentrations on the high $N$ input of $1500 \mathrm{mg} / \mathrm{kg} \mathrm{W}^{0.75}$ per d increased throughout the period of 6 weeks, they were not statistically different from their initial values at any time $\left(P>0.05 ; 1500 \mathrm{mg} v\right.$. initial $500 \mathrm{mg} / \mathrm{kg} \mathrm{W}^{0.75}$ per $\mathrm{d}$ within the group). The decrements of TP concentration continued through the period of 6 weeks on the low $\mathrm{N}$ input of $50 \mathrm{mg} / \mathrm{kg} \mathrm{W}^{0.75}$ per d and became significant $(P=0.045)$ after 2 weeks when compared with the initial values $\left(50 v\right.$. initial $500 \mathrm{mg} / \mathrm{kg} \mathrm{W}^{0.75}$ per $\mathrm{d}$ within the group).

The plasma volume, concentration and content of TP in the sheep in Expt 3 are shown in Fig. 5. After the $\mathrm{N}$ input was reduced from 500 to 100 or $10 \mathrm{mg} / \mathrm{kg} \mathrm{W}^{0.75}$ per d, plasma volume reduced substantially within the first week, continued to reduce although more slowly over the second week, and stabilized thereafter. TP concentrations declined gradually through the periods of 6 or 4 weeks, and the decrements from the initial values became statistically significant after 2 weeks on the $N$ input of $100 \mathrm{mg} / \mathrm{kg} \mathrm{W}^{0.75}$ $(P=0.025)$ but after only 1 week on the $\mathrm{N}$ input of $10 \mathrm{mg} / \mathrm{kg} \mathrm{W}^{0.75}(P<0.001)$ (i.e. 100 or $10 \mathrm{mg} v$. initial $500 \mathrm{mg} / \mathrm{kg} \mathrm{W}^{0.75}$ per d). TP contents, which were calculated by multiplying plasma volume and TP concentration, fell significantly over the first week $\left(P=0.04\right.$ and 0.03 respectively for the $\mathrm{N}$ inputs of 100 and $10 \mathrm{mg} / \mathrm{kg} \mathrm{W}^{0.75}$ per d), and 

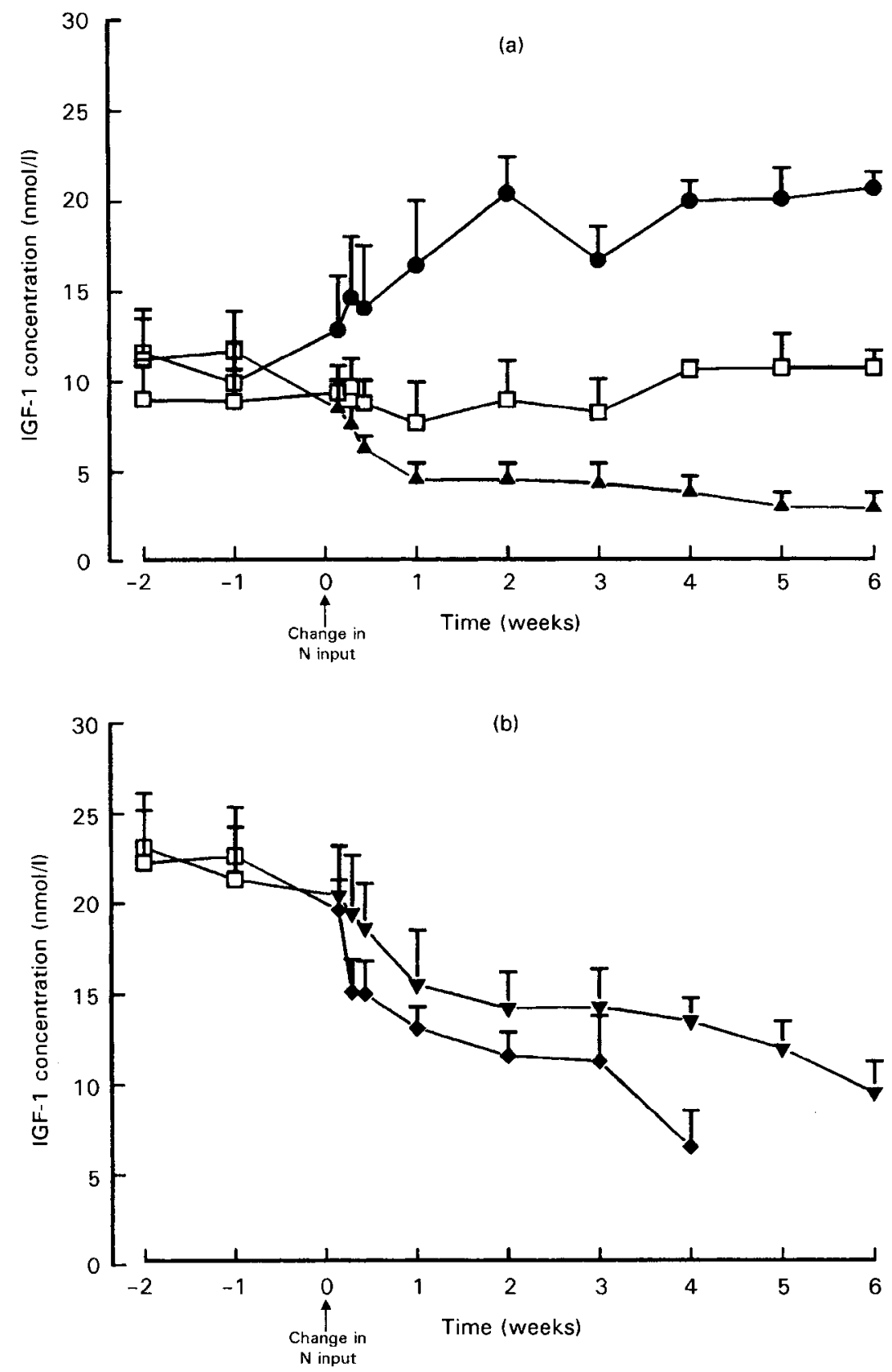

Fig. 3. Serum insulin-like growth factor-1 (IGF-1) concentrations (nmol/1) in sheep from (a) Expt 2 and (b) Expt 3. Sheep were infused with a constant amount of volatile fatty acids $\left(500 \mathrm{~kJ} / \mathrm{kg} \mathrm{W}^{0.75}\right.$ per d) and varying amounts of casein: $(\bullet), 1500 ;(\square), 500 ;(\nabla), 100 ;(\Delta), 50$ and $(\diamond), 10 \mathrm{mg} \mathrm{N} / \mathrm{kg} \mathrm{W}^{0.75}$ per d. Values are means with their standard errors represented by vertical bars for three sheep in each group except the $50 \mathrm{mg} / \mathrm{kg} \mathrm{W}^{0.75}$ per $\mathrm{d}$ input group, in which $n 4$. 

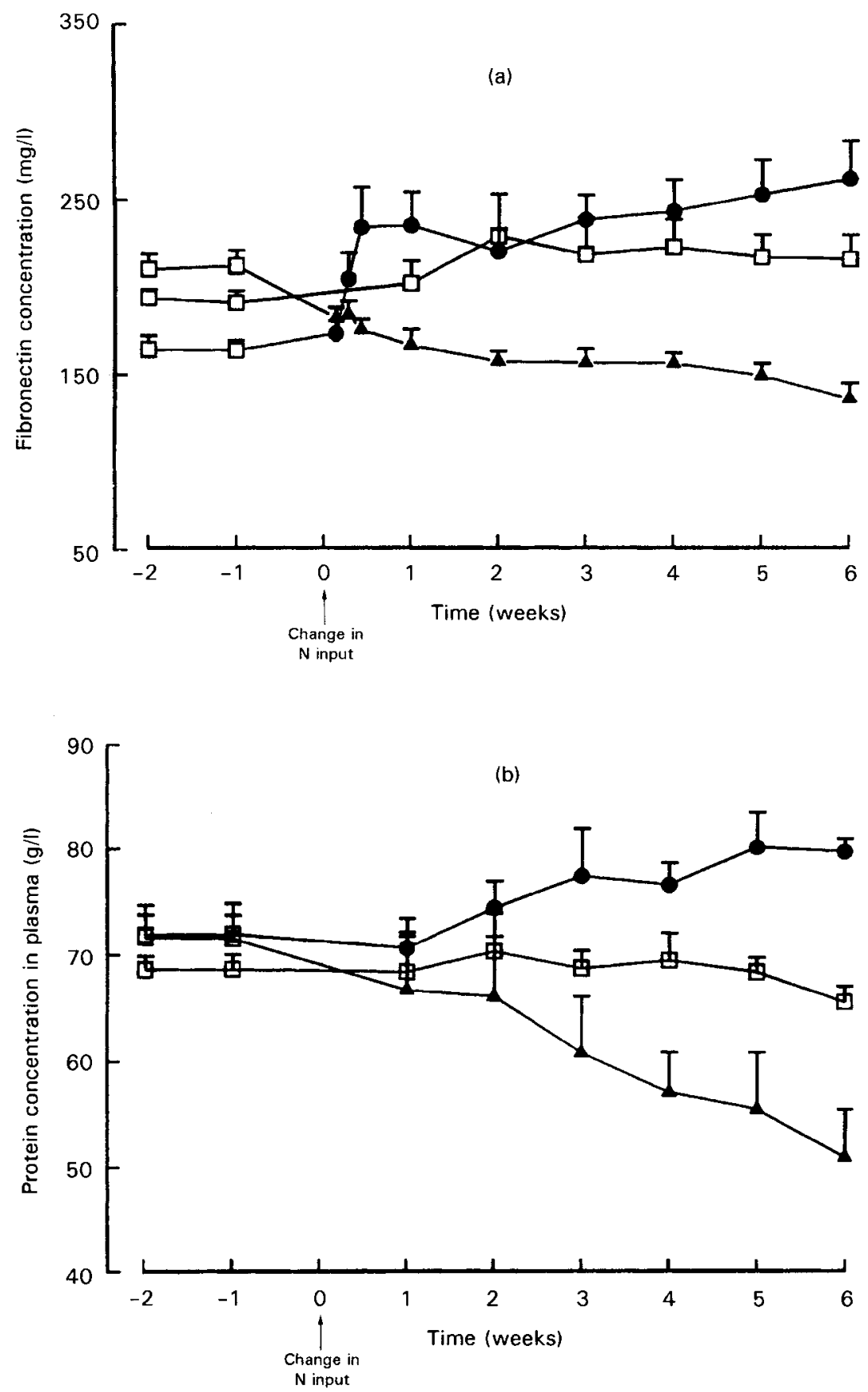

Fig. 4. Expt 2. Plasma concentrations of (a) fibronectin and (b) total protein in sheep infused with a constant amount of volatile fatty acids $\left(500 \mathrm{~kJ} / \mathrm{kg} \mathrm{W}^{0.75}\right.$ per d) and varying amounts of casein: (O), 1500; $(\square), 500$ and (A), $50 \mathrm{mg}$ $\mathrm{N} / \mathrm{kg} \mathrm{W}^{0.75}$ per $\mathrm{d}$. Values are means with their standard errors represented by vertical bars for three sheep in each group except the $50 \mathrm{mg} \mathrm{N} / \mathrm{kg} \mathrm{W}^{0.75}$ per $\mathrm{d}$ input group, in which $n 4$. 

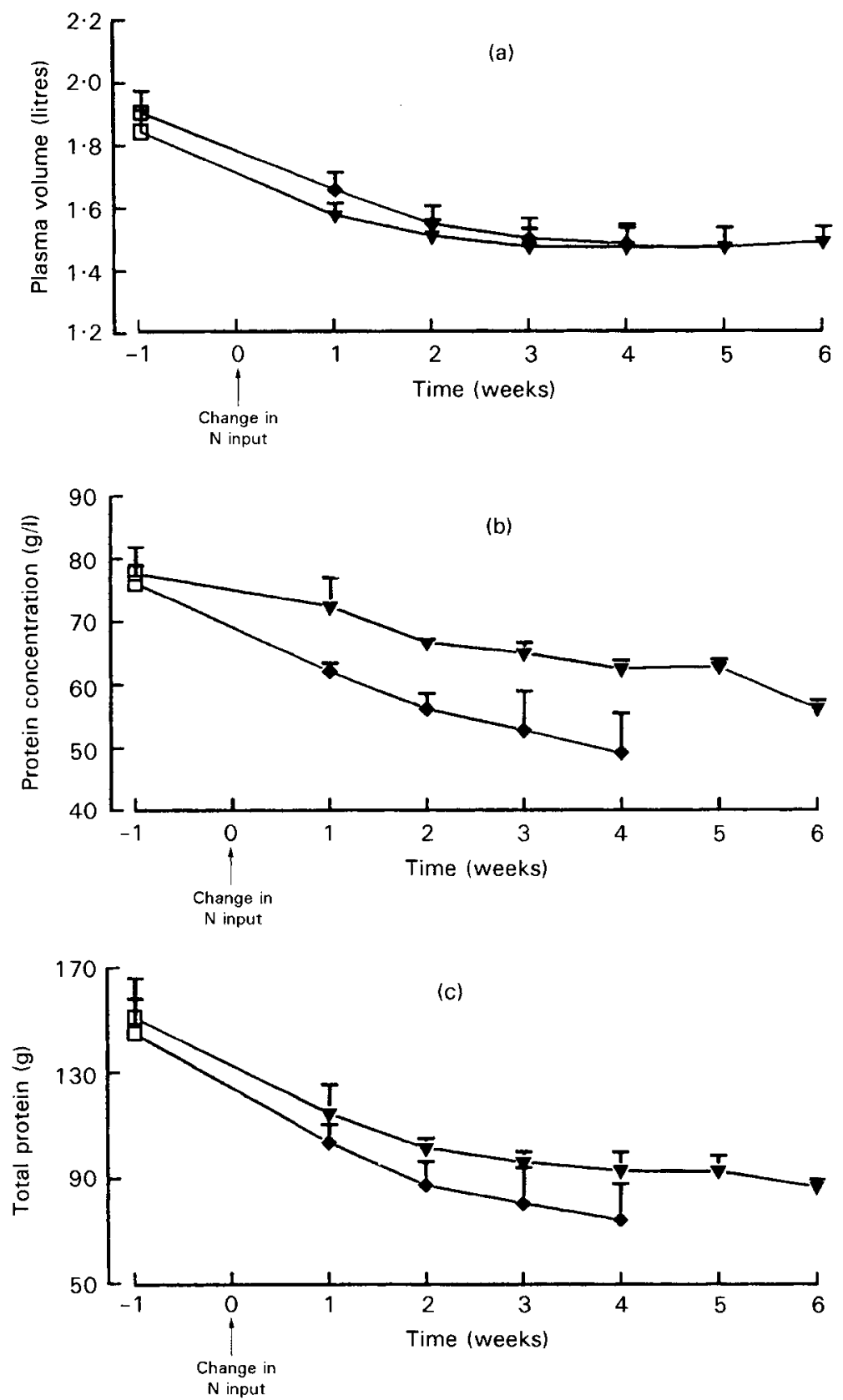

Fig. 5. Expt 3. (a) Plasma volume, (b) plasma protein concentration and (c) plasma total protein content in sheep infused with a constant amount of energy ( $500 \mathrm{~kJ} / \mathrm{kg} \mathrm{W}^{0.75}$ per d) in the form of volatile fatty acids + glucose, and with varying amounts of casein: $(\square), 500 ;(\nabla), 100$ and $(\diamond), 10 \mathrm{mg} \mathrm{N} / \mathrm{kg} \mathrm{W}^{0.75}$ per $\mathrm{d}$. Values are means for three sheep, with their standard errors represented by vertical bars. Total protein content in plasma was calculated by multiplying protein concentration and plasma volume. 
gradually until the end of the treatment periods. Although there were no statistically significant differences between the two groups at any time $(P>0.05)$, the lower $\mathrm{N}$ input of $10 \mathrm{mg} / \mathrm{kg} \mathrm{W}^{0.75}$ per $\mathrm{d}$ tended to result in greater decrements in the TP content and concentrations with time.

\section{DISCUSSION}

\section{The effect of exogenous nitrogen input on insulin-like growth factor-1, fibronectin and plasma total protein concentrations}

IGF- 1 concentrations were associated with the levels of $N$ inputs in both the steers and the sheep, and to energy inputs in the steers. These findings are in agreement with previous studies in lambs and sheep (MacRae et al. 1990, 1991; Kriel et al. 1992; Hua et al. 1993) and in cattle (Breier et al. 1986; Elsasser et al. 1989). In our steer experiment where the $N$ infused was increased gradually from 0 up to $2500 \mathrm{mg} / \mathrm{kg} \mathrm{W}^{0.75}$ per $\mathrm{d}$ at a short period of $5 \mathrm{~d}$ intervals, IGF-1 concentrations increased linearly over the whole range. However, when the $\mathrm{N}$ input was altered and maintained constantly high or low in the sheep, the changes of IGF-1 concentrations were both acute and substantial over the first few days, and then declined and finally ceased within 2 weeks on the high $\mathrm{N}$ input. These results indicate that responses of IGF-1 concentration were consistent over a wide range of $\mathrm{N}$ inputs, and the change in the concentration may be used as a sensitive indicator to exogenous protein and energy inputs.

This study is the first to report a significant effect of $\mathrm{N}$ input on plasma $\mathrm{FN}$ concentrations in both the steers and the sheep. The results are similar to those observed in human subjects. For example, substantial declines in plasma FN concentrations occur in human subjects in response to a period of starvation or to acute nutritional deprivation, while re-alimentation or nutritional therapy normalize the reduced concentrations (Scott $e t$ al. 1982; Chadwick et al. 1986). Low FN concentrations are often found in malnourished adults and young children, and the concentrations are increased by nutritional support, indicating improved dietary nutrient supplies (Yoder et al. 1987; Buonpane et al. 1989; Young et al. 1989). In the present study with sheep, acute changes in FN concentration were observed during the first $3 \mathrm{~d}$ on either the high or low $\mathrm{N}$ input. This could be partially due to the high turnover rate of $\mathrm{FN}$ in the body. Carraro et al. (1991) measured the fractional synthesis rate of FN in humans with labelled $\left[{ }^{15} \mathrm{~N}\right]$ glycine and $\left[1,2-{ }^{13} \mathrm{C}\right]$ leucine, and found it to be $0.38 / \mathrm{d}$. The half-life of FN observed in rats was $15-20 \mathrm{~h}$ (Saba \& Jaffe, 1980 ) or $25 \mathrm{~h}$ in human subjects (Pussell et al. 1985), i.e. the turnover rates were $0.95 / \mathrm{d}$ and $0.67 / \mathrm{d}$ respectively (calculated as turnover rate $=0.693 \div$ half life; Waterlow et al. 1978). Such a high turnover rate of FN implies that its metabolism and the concentration may be fairly sensitive to any alteration in dietary protein supply.

The concentration of TP did not show significant changes over a short period, such as $5 \mathrm{~d}$ intervals in the steer, and over the first week in the sheep on the high or low $\mathrm{N}$ inputs. However, the plasma concentrations in the sheep on the three low $\mathrm{N}$ inputs of 1500,500 and $50 \mathrm{mg} / \mathrm{kg} \mathrm{W}^{0.75}$ per d did show gradual and continuous declines, and the decrements became statistically significant within 2 weeks of treatment. These results indicate that TP concentration was not sensitive to small, short-term changes in protein status, but was related to severe, long-term body protein depletion. TP concentration of plasma is generally determined by TP content, plasma volume and the exchange rate of the protein between extra- and intravascular spaces. Plasma protein is mainly produced in the liver, and its synthesis accounts for approximately $25-40 \%$ of the protein synthesized in the liver (Garlick, 1980; Lobley, 1993). It has been found that the liver mass responds rapidly 
to dietary nutritional changes (Coward et al. 1977), and liver total protein synthesis (Lobley et al. 1992, 1994) and plasma protein synthesis (Kirsch et al. 1968; McNurlan et al. 1979) reflect dietary nutrient intakes. Therefore, it may be that TP content of plasma could respond rapidly to altered $N$ input. This was confirmed in the sheep in Expt 3 where the content of TP declined significantly when the N inputs were reduced from 500 to 100 or $10 \mathrm{mg} / \mathrm{kg} \mathrm{W}^{0.75}$ per $\mathrm{d}$. However these declines were partially compensated by the reductions in plasma volume, which altered rapidly with the changes in $\mathrm{N}$ inputs. The protein concentration therefore did not change significantly over a short period, and appeared not to be able to indicate a rapid change in protein status.

\section{The effect of protein status on insulin-like growth factor-1, fibronectin and total protein concentrations in sheep}

In the present sheep experiments, time-related changes in the concentrations of IGF-1, FN and TP were observed, in particular on the low $\mathrm{N}$ inputs. Since the daily $\mathrm{N}$ inputs were maintained constant over the 6-week treatment period, those time-related changes must have resulted from altered protein status. Although IGF-1, FN and TP function differently in the body, they are peptides or proteins, and changes in supplies of their constituent amino acids would influence their metabolism. In Expt 2, whole-body amino acid flux and protein synthesis were measured by a constant infusion of $\left[1-{ }^{13} \mathrm{C}\right]$ leucine (Liu et al. 1995). It was found that the changes in the total flux and synthesis $(\mathrm{g} / \mathrm{d})$ through the 6-week period of treatment were related to the gradual alterations in protein status when the $\mathrm{N}$ input was maintained constantly high or low. Those altered amino acid fluxes, i.e. the precursor pool for protein synthesis, would control the synthesis and, in turn, the circulating concentrations of FN and plasma protein. On the other hand, since IGF-1 is an anabolic regulator, its decrease could result in a further reduction in protein synthesis.

The changes in the concentrations of IGF-1, FN and TP in the sheep over the treatment periods differed between body protein accretion and depletion: they each reached plateau by 2 or 3 weeks on the high $\mathrm{N}$ input but declined continuously on the low $\mathrm{N}$ inputs. Since plasma IGF-1, most plasma proteins and the circulating FN are mainly produced in the liver, these different response patterns may indicate that the production rate of the liver could be rapidly saturated at an excess of $\mathrm{N}$ supply, but during protein depletion it would be closely related to nutrient flows into it. In other words, the liver has a high potential to take up nutrients in poor nutritional states. With its major blood flow contributed from the portal vein (Lobley et al. 1995) which carries most of the absorbed amino acids, the liver must have been very sensitive to changes in absorbed nutrients. In general, therefore, exogenous nutrients have the greatest influence on liver metabolism but, when these are limited, endogenous sources will contribute proportionally more and, thus, the effect of protein status could be more significant.

\section{The relationships between the protein status and total protein in sheep}

TP concentration of plasma was found to be highly correlated to progressive loss of body protein (CNB/TN, \%) in the sheep, as shown in Fig. 6, and it may, therefore, be used to indicate a loss of whole-body protein. Regression analysis was performed individually for the four sheep on the low $\mathrm{N}$ inputs of $50 \mathrm{mg} / \mathrm{kg} \mathrm{W}^{0.75}$ per $\mathrm{d}$ in Expt 2, and six sheep on the 100 and $10 \mathrm{mg} \mathrm{N} / \mathrm{kg} \mathrm{W}^{0.75}$ per d respectively in Expt 3 . The correlation coefficients ranged from 0.89 to $0.96(P<0.01)$, and the regression coefficients varied between 0.40 and $1 \cdot 10$. Since a small number of animals were used, with large individual variations, the 


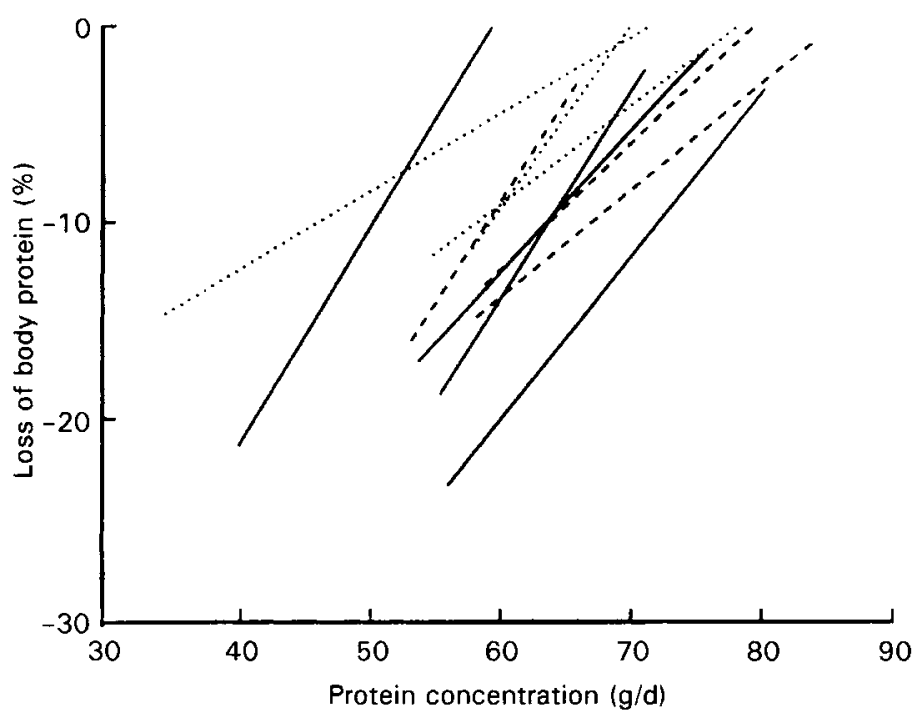

Fig. 6. The relationships between plasma total protein concentration $(\mathrm{g} / \mathrm{d})$ and the loss of body protein in sheep infused with casein at different levels: $(-\cdots), 100 ;(-), 50$ and $(\cdots) 10 \mathrm{mg} \mathrm{N} / \mathrm{kg} \mathrm{W}^{0.75}$ per d. Infusion of non-protein energy from volatile fatty acids + glucose was constant at $500 \mathrm{~kJ} / \mathrm{kg} \mathrm{W}^{0.75}$ per $\mathrm{d}$. The body protein loss was calculated as a percentage of the cumulative nitrogen loss through the treatment periods of 6 or 4 weeks in relation to the initial total body nitrogen at maintenance. Data presented are from the four sheep receiving $50 \mathrm{mg} \mathrm{N} / \mathrm{kg} \mathrm{W}^{0.75}$ per d in Expt 2 and three sheep in the other two groups (Expt 3). The correlation coefficients of the continuous losses of body protein with the gradual declines in plasma total protein concentration for each individual sheep ranged from 0.89 to $0.96(P<0.01)$. Regression lines were derived for each sheep and are plotted in the Fig. There was no significant difference $(P>0 \cdot 05)$ in the slopes between the three nitrogen inputs. The average of all ten slopes is 0.78 (SD 0.25 ).

differences in the regression coefficients were not statistically significant $(P=0 \cdot 24)$ between the three low $\mathrm{N}$ inputs of 100,50 and $10 \mathrm{mg} / \mathrm{kg} \mathrm{W}^{0.75}$ per $\mathrm{d}$. In fact, these three $\mathrm{N}$ inputs per se are very low. The actual amounts of $\mathrm{N}$ input $(0.16$ to $1.6 \mathrm{~g} / \mathrm{d})$ were so small that the differences in protein depletion and plasma protein concentration were unlikely to be detected by the methods employed. Even so, the progressive loss of body protein with time in the sheep on the low $\mathrm{N}$ inputs was consistently accompanied by the gradual decrease in plasma protein concentration.

The average of the ten regression coefficients in Fig. 6 was 0.78 (SD 0.25). Given that other variables are constant, this implies that every $10 \mathrm{~g} / 1$ decline in plasma protein concentration may be associated with a loss of approximately $8 \%$ of body protein. Caution is required to explain changes in plasma protein concentration because of large individual variations. Furthermore, these relationships between body protein loss and plasma protein concentration were defined with the sheep nourished by intragastric nutrient infusions. Further studies may be required for sheep fed on conventional diets. Sykes (1978) obtained a linear relationship of plasma albumin concentration $(\mathrm{g} / \mathrm{l})$ with percentage loss of body protein in pregnant ewes fed on semi-purified diets at low protein intakes $(20-100 \%$ of the requirement). Our findings are in line with that study.

To compare relative changes in the loss of plasma protein with that of whole-body protein in the sheep on the $\mathrm{N}$ inputs of 100 and $10 \mathrm{mg} / \mathrm{kg} \mathrm{W}^{0.75}$ per $\mathrm{d}$ in Expt 3, the plasma protein- $\mathrm{N}$ (protein $\times 0.16$ ) 'loss' was calculated as the difference in the protein contents between two consecutive weeks. Plasma protein- $\mathrm{N}$ losses accounted for approximately $28 \%$ of the total body $\mathrm{N}$ loss over the first week, remained as high as $11 \%$ over the second 
week, and then stabilized at $3.8 \%$ over the following weeks. These data suggest that plasma protein was greatly reduced compared with the other tissues in the early stage of protein depletion, but in the late stage of depletion, after approximately 2 or 3 weeks of treatment, plasma protein loss was synchronized with the depletion of body protein. However, those rapid declines in total content of plasma protein were compensated partially by the declines in plasma volume, and the concentration of TP, therefore, did not fall as fast as the total content. In the sheep on the low $\mathrm{N}$ inputs of 100, 50 and $10 \mathrm{mg} / \mathrm{kg} \mathrm{W}^{0.75}$ per $\mathrm{d}$, the low $\mathrm{N}$ input-induced decrements in TP concentration took 2 weeks to become statistically different from the initial value. The body total $\mathrm{N}$ loss was approximately 6-8\% over these 2 weeks. Therefore a slight body protein depletion was not linked to the change in plasma concentration of TP, but could be indicated by its total content.

\section{CONCLUSION}

The results of the experiments with steers and with sheep suggest that the acute responses of the concentrations of serum IGF-1 and plasma FN mainly resulted from the alterations in exogenous $\mathrm{N}$ input, and their chronic decrements were further influenced by body deprivation. Reductions in $\mathrm{N}$ input to sub-maintenance resulted in acute declines in total content of plasma protein. Significant declines in concentration of plasma protein were associated with severe, long-term body protein depletion.

The authors gratefully acknowledge the help of the Animal Service Group in preparing and looking after the animals, and of Mr R. I. Smart for analysis of urine-N, Mr L. A. Bruce for help with the measurement of IGF-1, Dr S. Robins for providing the ELISA method. We are appreciative of Dr G. E. Lobley at the Rowett Research Institute, Aberdeen and of Dr N. R. Adams at the Commonwealth Scientific and Industrial Research Organization, Australia for their useful comments. S. M. Liu is a recipient of a postgraduate award from the Sino-British Friendship Scholarship Scheme. This work was partly supported by the Scottish Office Agriculture and Fisheries Department.

\section{REFERENCES}

Agricultural Research Council (1980). The Nutrient Requirements of Ruminant Livestock, pp. 39-40, 49, 129. Slough: Commonwealth Agricultural Bureaux.

Baxter, R. C. (1986). The somatomedins: insulin-like growth factors. Advances in Clinical Chemistry 25, 49 115.

Breier, B. H., Bass, J. J., Butler, J. H. \& Gluckman, P. D. (1986). The somatotrophic axis in young steers: influence of nutritional status on pulsatile release of growth hormone and circulating concentrations of insulinlike growth factor-1. Journal of Endocrinology 111, 209-215.

Bruce, L. A., Atkinson, T., Hutchinson, J. S., Shakespear, R. A. \& MacRae, J. C. (1991). The measurement of insulin-like growth factor-1 in sheep plasma, Joumal of Endocrinology 128, R1-R4.

Buonpane, E. A., Brown, R. O., Boucher, B. A., Fabian, T. C. \& Luther, W. L. (1989). Use of fibronectin and somatomedin-C as nutritional markers in the enteral nutrition support of traumatized patients. Critical Care Medicine 17, 126-132.

Carraro, F., Rosenblatt, J. \& Wolfe, R. R. (1991). Isotopic determination of fibronectin synthesis in humans. Metabolism 40, 553-561.

Chadwick, S. J., Sim, A. J. \& Dudley, H. A. (1986). Changes in plasma fibronectin during acute nutritional deprivation in healthy human subjects. British Journal of Nutrition 55, 7-12.

Clemmons, D. R. \& Underwood, L. E. (1991). Nutrition regulation of IGF-1 and IGF binding proteins. Annual Review of Nutrition 11, 393-412.

Coward, W. A., Whitehead, R. G. \& Lunn, P. G. (1977). Reasons why hypoalbuminaemia may or may not appear in protein-energy malnutrition. British Journal of Nutrition 38, 115-126. 
Davidson, J., Mathieson, J. \& Boyne, A. W. (1970). The use of automation in determination of nitrogen by the Kjeldahl method, with final calculation by computer. Analyst 95, 181-193.

Ellis, K. J. (1992). Measurement of whole-body protein content in vivo. In Modern Methods in Protein Nutrition and Metabolism, pp. 195-223 [S. Nissen, editor]. San Diego: Academic Press, Inc.

Elsasser, T. H., Rumsey, T. S. \& Hammond, A. C. (1989). Influence of diet on basal growth hormone-stimulated plasma concentrations of IGF-1 in beef cattle. Journal of Animal Science 67, 128-141.

Foldager, N. \& Blomqvist, C. G. (1991). Repeated plasma volume determination with the Evans Blue dye dilution technique: the method and a computer program. Computer Biological Medicine 21, 35-41.

Garlick, P. J. (1980). Protein turnover in the whole animal and specific tissues. In Comprehensive Biochemistry Protein Metabolism, vol. 19B, pp. 77-154 [P. J. Garlick and D. J. Millward, editors]. Amsterdam: Elsevier.

Gibson, R. S. (1990). Assessment of protein status. In Principles of Nutritional Assessment, pp. 307-348 [R. S. Gibson, editor]. Oxford: Oxford University Press.

Gornall, A. G., Bardawill, C. J. \& David, M. M. (1949). Determination of serum proteins by means of the biuret reagent. Journal of Biological Chemistry 177, 751-766.

Hua, K. M., Ord, R., Li, Q. J., Hodgkinson, S. C., Spencer, G. S. G., Molan, P. C. \& Bass, J. J. (1993). Regulation of plasma and tissue levels of insulin-like growth factor-1 by nutrition and treatment with growth hormone in sheep. Journal of Endocrinology 136, 217-224.

Kirby, D. F., Marder, R. J., Craig, R. M., Eskildsen, R. \& Middaugh, P. (1985). The clinical evaluation of plasma fibronectin as a marker for nutritional depletion and repletion and as a measure of nitrogen balance. Journal of Parenteral and Enteral Nutrition 9, 705-708.

Kirsch, R., Firth, L., Black, E. \& Hoffenberg, R. (1968). Regulation of albumin synthesis and catabolism by alteration of dietary protein. Nature 217, 578-579.

Kriel, G. V., Bryant, M. J. \& Lomax, M. A. (1992). Effect of dietary protein intake and intravenous glucose infusion on plasma concentrations of insulin-like growth factor-1 in lambs. Journal of Endocrinology 132 , 915-919.

Lawes Agricultural Trust (1993). Genstat(1MI) 5, Release 3 Reference Manual. Oxford: Oxford Science Publications, Clarendon Press.

Liu, S. M., Lobley, G. E., MacLeod, N. A., Kyle, D. J., Chen, X. B. \& Ørskov, E. R. (1995). Effects of long-term protein excess or deficiency on whole-body protein turnover in sheep nourished by intragastric infusion of nutrients. British Journal of Nutrition 73, 829-839.

Lobley, G. E. (1993). Protein metabolism and turnover. In Quantitative Aspects of Ruminant Digestion and Metabolism, pp. 313-339 [J. M. Forbes and J. France, editors]. Wallingford: CAB International.

Lobley, G. E., Connell, A., Lomax, M. A., Brown, D. S., Milne, E., Calder, A. G. \& Farningham, D. A. H. (1995). Hepatic detoxification of ammonia in the ovine liver: possible consequences for amino acid catabolism. British Journal of Nutrition 73, 667-685.

Lobley, G. E., Connell, A., Milne, E., Newman, A. \& Ewing, T. A. (1994). Protein synthesis in splanchnic tissues of sheep offered two levels of intake. British Journal of Nutrition 71, 3-12.

Lobley, G. E., Harris, P. M., Skene, P. A., Brown, D., Milne, E., Calder, A. G., Anderson, S. E., Garlick, P. J., Nevison, I. \& Connell, A. (1992). Responses in tissue synthesis to sub- and supra-maintenance intake in young growing sheep: comparison of large-dose and continuous-infusion techniques. British Journal of Nutrition $\mathbf{6 8}$, 373-388.

MacLeod, N. A., Corrigall, W., Stirton, R. A. \& Ørskov, E. R. (1982). Intragastric infusion of nutrients in cattle. British Journal of Nutrition 47, 547-552.

McNurlan, M. A., Tomkins, A. M. \& Garlick, P. J. (1979). The effect of starvation on the rate of protein synthesis in rat liver and small intestine. Biochemical Journal 178, 373-379.

MacRae, J. C., Bruce, L. A., Hovell, F. D. DeB., Hart, I. C., Inkster, J., Walker, A. \& Atkinson, T. (1991). Influence of protein nutrition on the response of growing lambs to exogenous bovine growth hormone. Journal of Endocrinology 130, 53-61.

MacRae, J. C., Inkster, J., Bruce, L. A., Hovell, F. D. DeB. \& Atkinson, T. (1990). Interaction between protein supply and the effect of growth hormone administration on plasma insulin-like growth factor-1 concentrations in infusion-maintained lambs. Proceedings of the Nutrition Society 49, 155A.

Ørskov, E. R. \& MacLeod, N. A. (1982). The determination of the minimal nitrogen excretion in steers and dairy cows and its physiological and practical implications. British Journal of Nutrition 47, 625-636.

Pussell, B. A., Peake, P. W., Brown, M. A. \& Charlesworth, J. A. (1985). Human fibronectin metabolism. Journal of Clinical Investigation 76, 143-148.

Saba, T. M. \& Jaffe, E. (1980). Plasma fibronectin (opsonic glycoprotein): its synthesis by vascular endothelial cells and role in cardiopulmonary integrity after trauma as related to reticuloendothelial function. American Journal of Medicine 68, 577-594.

Scott, R. L., Sohmer, P. R. \& MacDonald, M. G. (1982). The effect of starvation and repletion on plasma fibronectin in man. Journal of the American Medical Association 248, 2025-2027.

Sykes, A. R. (1978). An assessment of the value of plasma urea nitrogen and albumin concentrations as monitors of the protein status of sheep. In Blood Profile in Animal Production. British Society of Animal Production Occasional Publication no. 1, pp. 143-154 [D. Lister, editor]. Milton Keynes: BSAP. 
Tamkun, J. W. \& Hynes, R. O. (1983). Plasma fibronectin is synthesized and secreted by hepatocytes. Journal of Biological Chemistry 258, 4641-4647.

Voller, A. \& Bidwell, D. (1980). The Enzyme Linked Immunosorbent Assay (ELISA), Vol. 1. London: Nuffield Laboratory of Comparative Medicine, Institute of Zoology.

Waterlow, J. C., Garlick, P. J. \& Millward, D. J. (1978). Protein Turnover in Mammalian Tissues and in Whole Body, pp. 287-288. Amsterdam, New York and Oxford: North-Holland Publishing Company.

Yoder, M. C., Anderson, D. C., Gopalakrishna, G. S., Douglas, S. D. \& Polin, R. A. (1987). Comparison of serum fibronectin, prealbumin, and albumin concentrations during nutritional repletion in protein-calorie malnourished infants. Journal of Paediatric Gastroenterology and Nutrition 6, 84-88.

Young, G. A., Zeiderman, M. R., Thompson, M. \& MacMahon, M. J. (1989). Influence of preoperative intravenous nutrition upon hepatic protein synthesis and plasma proteins and amino acids. Journal of Parenteral and Enteral Nutrition 13, 596-602.

Young, V. R., Marchini, J. S. \& Cortielia, J. (1990). Assessment of protein nutritional status. Journal of Nutrition 120, Suppl. 11, 1496-1502. 